Л. К. Гливінська

\title{
АВТОРСЬКИЙ СЛОВНИК: ДО ПИТАННЯ ПРО КАТЕГОРІЙНУ СПЕЦИФІКУ Й ТЕОРЕТИКО-ПРИКЛАДНУ ЗНАЧУЩІСТЬ
}

Гливінська Л. К. Авторський словник: до питання про категорійну специфіку й теоретико-прикладну значущість.

У статті висвітлено проблематику авторської лексикографії. Розглянуто базові термінопоняття означеної лінгвістичної галузі. 3'ясовано роль письменницьких словників у формуванні загальномовної норми. Аргументовано перспективність лексикографічної параметризації художніх текстів.

Ключові слова: лексикографія, авторський словник, параметризація, художній текст.

Гливинская Л. К. Авторский словарь: к вопросу о категориальной специфике и теоретико-прикладной значимости.

В статье освещена проблематика авторской лексикографии. Рассмотрены базовые терминопонятия указанного лингвистического направления. Определена роль писательского словаря в формировании общеязыковой нормы. Аргументирована перспективность лексикографической параметризации художественных текстов.

Ключевые слова: лексикография, авторский словарь, параметризация, художественный текст.

Hlyvinska L. K. Author's dictionary: categorial specifics and theoretical-applied significance.

The article covers the problematics of author's lexicography. It researches the basic notions of the stated linguistic line, defines the role of author's dictionary in forming common language standards, and presents arguments for perspectivity of literary text lexicographic parameterization.

Key words: lexicography, author's dictionary, parameterization, literary text.

У лінгвістичній науці третього тисячоліття лексикографія зберігає статус перспективної галузі й залишається, напевно, найбільш відкритою до реалізації актуальних дослідницьких запитів, орієнтованих значною 
мірою на міждисциплінарний підхід. Антропоцентрична ідеологія, що детермінувала нинішню магістральну скерованість лінгвістики, синтезує, як відомо, різні способи вивчення «мови в людині» й «людини в мові» (когнітивний, етнолінгвістичний, прагмалінгвістичний, лінгвофілософський, соціолінгвістичний та ін.). Відтак на тлі інтерпретативного плюралізму актуалізується проблема лексикографічного форматування всіх результатів багатоаспектного лінгвістичного опису. Зрештою, створенню словників, граматик, а віднедавна - ще й електронних текстових корпусів підпорядковано ключові завдання мовознавчої науки.

Показовий матеріал для досліджень містять авторські словники, що в доцільній формі узагальнюють факти лінгвальної практики творчих особистостей (зокрема літераторів, публіцистів, філософів). Сама традиція лексикографічного «портретування» авторських текстів укотре засвідчує, що антропоцентризм мови потребує антропоорієнтованих підходів. I така скерованість авторського словникарства виразно корелює 3 настановами сучасної лінгвістики.

Українські вчені послідовно наголошують на історичній, гносеологічній, культурологічній цінності авторських лексиконів. Заявлену проблематику висвітлено в роботах С. Бук, Г. Вокальчук, П. Гриценка, В. Грещука, Н. Данилюк, Л. Дядечко, М. Карпенко, А. Мойсієнка, Н. Сологуб, 3. Терлака, Т. Цимбалюк-Скопненко та інших гуманітаріїв. Загалом визнаючи здобутки, що їх має вітчизняна наука у сфері параметризації авторського мовлення, дослідники твердять усе ж про незадовільний стан означеної лінгвістичної галузі [8, с. 16]. Пор. також: «...між періодами виходу у світ українських словників зяють прірви непрощенної неактивності. <..> Українським словникарям треба вивчити досвід інших... країн, щоб належним чином оцінити власний. Потрібен час і змога шукати й узагальнювати» [23, с. 8, 11].

У світлі сказаного актуальність нашої статті видається обгрунтованою. Мета дослідження - проаналізувати авторський словник у його понятійній специфіці (на рівні базового категорійного апарату); означити роль письменницьких лексиконів у становленні мовної норми; розглянути потенціал авторського словникарства в контексті загальнолінгвістичних завдань.

Важливо, що формування й подальше утвердження наукових підходів до лексикографічного аналізу мовної особистості пов'язані з вивченням лінгвальної майстерності творців художньої літератури. Відтак у східнослов' янській філологічній традиції набула поширення терміносполука «письменницька лексикографія» [2; 5; 25, с. 11]. Поняття «поетична лексикографія» іноді наділяють тим самим змістом або використовують його у вужчому значенні - $з$ проекцією на матеріал тільки віршової мови [7]. Термін «авторська лексикографія» домінує в сучасній світовій практиці [27], проте в українських спеціалізованих довідниках ще не дістав офіційного закріплення (див., напр., у виданні [21] статті 
«Лексикографія», «Словник», «Мови письменника словник»).

Загалом аргументи фахівців на користь того чи того термінопоняття $€$ по-своєму переконливими. Так, інтернаціональний характер номінації «авторська лексикографія» (пор.: author (author's) lexicography / dictionary, Autorenlexikographie) - привід для іiі залучення в науковий обіг, зокрема й щодо аналізу художньої мови. Уточнювальні терміни «письменнищька лексикографія», «письменницький словник» доцільно використовувати для опису естетичної комунікації, зважаючи на семантичні відмінності в словах «автор» і «письменник» (пор.: автор - «той, хто написав будь-яку працю, твір, лист і т. ін. або розробив якийсь план, проект і т. ін.» [18 I, c. 13]; письменник - «той, хто пише художні твори; особа, для якої літературна діяльність є професією» [18 VI, с. 365].

Очевидно, що для проблематики конкретних досліджень родо-видова диференціація розглянутих понять може бути релевантною. Авторська лексикографія матиме в такому разі найширшу джерельну базу - ідіолекти не тільки літераторів, а й публіцистів, науковців, громадських та ін. діячів, соціолекти певного покоління, зокрема мистецького, певних шкіл, напрямів тощо. Об'єкт письменницької лексикографії становитиме мовотворчість поетів, прозаїків, драматургів. У загальному контексті письменницького словникарства водночас доцільно - з методологічного погляду - вирізняти поетичну лексикографію, орієнтовану на репрезентацію віршових текстів.

Зауважимо, що опис лінгвального досвіду визнаних носіїв мови, зокрема класиків національної літератури, «превалює в усіх відомих лексичних картотеках європейських мов і поширюється... майже на всі електронні текстові корпуси національного статусу» [10, с. 50]. А оскільки матеріал авторських словників так само здебільшого складають художні твори, практика ототожнення авторської лексикографії з письменницькою $\epsilon$ цілком виправданою. На підтвердження цьому додамо, що українська авторська нехудожня лексикографія нині представлена поодинокими виданнями. Так, ще на початку ХХ ст. Ю. Кобилянський упорядкував латинсько-український словник, залучивши до аналізу документальну хроніку античного політика, полководця й оратора Г. Юлія Цезаря [17]. В окремих джерелах здійснено параметризацію власне українськомовних текстів - наукових, публіцистичних, епістолярних тощо. При цьому особливий інтерес виявляють дослідники до авторів, знаних і як талановиті письменники. Скажімо, у «Словнику мовних особливостей Івана НечуяЛевицького» [14] узагальнено лінгвістичні погляди вченого на морфологічні й лексичні норми української літературної мови кінця XIX - початку $\mathrm{XX}$ ст. У «ясний і високий світ наукової мислі, ...чіткого літературознавчого стилю, що захоплює своєю логічністю і простотою» [15, с. 3], уводить «Словник літературознавчих термінів Івана Франка». Опис ідіолекту мислителя продовжено й в іншому виданні - словнику мовознавчих ๑ Л. К. Гливінська, 2013. 
термінів [16]. Предметом окремої уваги стала інтернаціональна складова наукового лексикону I. Франка [20]. Ще один оригінальний словник створено на матеріалі епістолярної спадщини Лесі Українки [3]. Новітній для вітчизняної лексикографії жанр репрезентує також словник-довідник «Фразеологія перекладів Миколи Лукаша» [22].

Принагідно зауважимо, що до категорії «авторських» належать словники, упорядковані, скажімо, одним автором-лексикографом. Крім того, логічно називати «письменницькими» різнотипні словники, створювані самими літераторами. (Серед представників українського письменства досвід лексикографічної роботи мали І. Котляревський («Словарь малороссийских слов, содержащихся в «Энеиде», с русским переводом», 20-ті pp. ХІХ ст.; вперше опублік. 1842 р.); М. Гоголь («Книга всякой всячины, или подручная энциклопедия Н. В. Гоголя за 1826 г.»; передрук. 1889 р.); Л. Боровиковський («Словник української мови 3 покажчиком коренів слів», 1836 р.); П. Білецький-Носенко («Словарь малороссийского или юго-восточнорусского языка...», 1838-1843 рр.; опублік. 1966 р.); Я. Головацький («Матеріялы для словаря Малорусскаго нарьчія...», 50-ті рр. ХІХ ст.; опублік. 1982 р.); Я. Кухаренко («Чабанський словарь», 1862 р.); І. Франко («Дітські слова в українській мові», 1881 р.); Б. Грінченко («Словарь української мови», 19071909 рр.); І. Нечуй-Левицький («Словар. Деякі народні й нові книжні слова (неологізми)», 1914 р.); Наталена Королева («Кишеньковий чесько-український словник», 1920-1921 рр.); В. Підмогильний і Є. Плужник («Фразеологія ділової мови», 1926-1927 pp.; «Російсько-український фразеологічний словник», 1928 р.) та інші митці.) А втім, погоджуємося, що така неоднозначність термінів «навряд чи може вплинути на їх сприйняття i на усталену практику використання спеціалістами-лексикографами» [24, с. 7].

На особливу увагу заслуговує питання про роль авторської лексикографіï як галузі кодифікаційної. Тут варто актуалізувати принаймні два моменти. 3 одного боку, можна твердити, що письменницький словник «впливає на кодифікацію літературної мови» і на певному етапі «стає виразником найголовніших нормалізаційних тенденцій» [23, с. 5]. Цікаво, до речі, що в англійській авторській лексикографії (а вона вважається найдавнішою) перші словники мали характер саме нормативного припису [13, с. 104]. I в цьому контексті доцільно підкреслити, що літературно-художній дискурс визнають вагомим джерелом «історії української літературної мови, надто якщо розглядати цю історію в аспекті відображення концептів національномовної свідомості» [11, с. 5]. Вітчизняні лінгвісти послідовно послуговуються художніми текстами i, добираючи з них стилістично доцільні вербальні засоби, культивують загальномовну норму. Пам'ятаємо й про те, що розвиток національних літературних мов неодмінно пов'язаний з іменами видатних майстрів художнього слова (Данте, Сервантес, Шекспір, Міцкевич, Пушкін, Шевченко та інші). 
3 іншого боку, треба визнати, що словники художньої мови $\epsilon$ описовими. I деякі лінгвісти обстоюють тільки цей підхід. Як наголошує Ю. Гінзбург, авторський словник «у жодному разі не може бути таким, що регламентує. Альтернатива «прескрипція - дескрипція» для словника письменника розв'язується на користь дескрипції: ...текст є художнім, якщо нормою стає систематичне відхилення від загальнообов'язкових правил мовної естетики» [5, с. 41]. Така позиція дослідника видається дискусійною; вважаємо, що підхід до художнього тексту як до системи відхилень від мовної норми не варто абсолютизувати. Водночас маємо визнати, що своєю творчістю письменник продукує власну - ідіолектну норму, і ця норма увиразнює авторське мовомислення. У зв'язку з цим знаходимо слушний коментар: «Традиція - це своєрідний умовний код, яким повинен володіти кожен автор для передачі естетичної інформації, а з іншого боку - це та система правил, яку митець прагне подолати, щоб виразити своє, індивідуально-неповторне бачення світу» [19, с. 21].

Важливо, що грунтовність лінгвістичної теорії безпосередньо залежить від того, наскільки вичерпним і послідовним є вивчення функціональних особливостей мови, реалізованих у художньому тексті. Саме в ситуації естетичного спілкування найчіткіше проступає діалектика загального й окремого, незалежно від ступеня відкритості й лінгвальної «впорядкованості» художнього образу.

Красне письменство являє мову, націлену на творчість, часом - на свідомий експеримент. Зрештою, передусім «в одежі слова» митець має віднайти джерела для репрезентації особистісного бачення світу. Думки й почуття одного автора матеріалізуються у звукосимволізмі, потенційній лексиці, у багатстві стилістичних фігур; лінгвальна практика іншого - семантично прозора, логічно злагоджена, граматично струнка. За будь-яких маніфестацій - у формозмістовій розкутості чи в дотриманні загальноприйнятого слововживання - має місце «творчий аспект мови» [7, с. 58], урахування якого в симбіозі з іншими аспектами становить надійний фундамент для теоретико-лінгвістичних висновків.

Авторські словники є продуктом раціонального дослідницького підходу. До такого переконання спонукають, напевно, і роздуми талановитого прозаїка: «Інтерпретації й коментарі творця до власної книжки не можуть мати переваги перед тлумаченнями й коментарями інших. Не письменник оцінює свій твір, а сам твір виносить присуд про письменника» [12, с. 39]. Словник як особлива форма структуризації художнього мовлення, безперечно, увиразнює «портрет» письменника. Погоджуємося, що «словник часто глибше розкриває сутнісні сторони мови, особливості їі структури та буття як феномену культури, аніж лінгвістичні праці інших типів» [9, с. 238].

Авторські словники надають відомості, що мають значну верифікаційну силу, а відтак до певної міри нейтралізують проблему впорядкування ○ Л. К. Гливінська, 2013. 
різнорідного фактичного матеріалу, яка з особливою гостротою постає перед фахівцем із лінгвопоетики. «Пошук цитат, невиразно збережених у пам'яті рядків, довідки про частоту і хронологію слововживань - усе те, що нерідко доводиться враховувати, стає значно простішим, а іноді й уперше можливим», - читаємо в рецензії на один із письменницьких словників [1, с. 278-279]. Цікаво, що деякі упорядники називають авторські лексикони «ключами» (the key), тим самим підкреслюють вагому роль таких словників у реконструкції мовної свідомості письменника (пор., напр.: Clarke Ch., Clarke M. C. The Shakespeare Key (London, 1879); Pierce G. A., Wheeler W. A. The Dickens Dictionary; a Key to the Characters and Principal Incidents in the Tales of Charles Dickens (Boston, 1872). А в сентенціях самих літераторів ця метафора набуває особливої значущості: «Для уважного критика словники - ключі до таємниць поетового духу» (Андрій Бєлий).

Прикметно, що поступ у розвитку національних літератур залежить 3-поміж іншого й від еволюції лексикографії. Так, П. Загребельний був переконаний, що без «Материалов для словаря древнерусского языка...» I. Срезневського «писати історичний роман - цілковите безглуздя. Адже досить письменникові припуститися кількох неточностей в історичній термінології, в мові, порушити історичний дух мови, як читацьку довіру буде втрачено одразу i, може, назавжди» [12, с. 39]. «Знаряддям виробництва» для літератора $є$ й авторські словники, через які митець також опановує техніку письменницької праці, засвоює класичні зразки художнього мовлення (наприклад, у пошуку потрібних рим поетові можуть допомогти словникиримівники). Цікаво, що розквіт, скажімо, французької літератури пов'язують із тривалою традицією лексикографічного опису французької художньої мови [4].

Натомість неналежна організація словникарської роботи, очевидно, перешкоджає динаміці літературної творчості. Разом із тим відсутність авторського словника не тільки сповільнює рефлексію щодо лінгвокреативної діяльності письменника, а й унеможливлює «з'ясування його індивідуальних мовних осягнень у їх відношенні до узусу, норми літературної мови» [8, c. 16]. Ці перепони у свою чергу віддаляють від експлікації асоціативного потенціалу загальнонародної мови, на якому грунтується й особлива виражальність словесного мистецтва. Л. Щерба, до речі, підкреслював, що підготовці загальномовного словника має передувати вичерпний лексикографічний аналіз творчості письменників [26, с. 269-270]. Тому поява антиномії «авторський словник - неавторський словник» у загальній лексикографічній типології є цілком закономірною (пор.: [26; 6]).

Можна припустити, що в контексті актуальних лінгвістичних реалій, пов'язаних з утвердженням антропоцентричного наукового світогляду, а також із розвитком комп'ютерних технологій, поступ украӥнського авторського словникарства набуватиме дедалі виразніших обрисів. Зокрема, на етапі структуризації категорійного апарату галузі доцільно враховувати, що у 
світовій практиці дістали поширення поняття «авторська лексикографія», «авторський словник», якими, по-перше, послідовно оперують, аналізуючи художній дискурс, i, по-друге, означують інтерпретативний підхід до мови публіцистів, перекладачів, науковців та інших творчих особистостей. Терміни «письменницька лексикографія», «поетична лексикографія», засвоєні східнослов'янською лінгвістичною традицією, можуть вказати на вибір континууму літературно-художнього конкретним матеріалом дослідження. Водночас пріоритетні тенденції у сфері лексикографічного «портретування» сигналізують про ототожнення авторського й письменницького словникарства.

Коментуючи роль авторських / письменницьких лексиконів у формуванні загальномовної норми підкреслимо, що матеріал таких видань потребує осмислення 3 погляду не лише дескриптивного, а й прескриптивного. До цього, зрештою, спонукає усталена практика залучення художніх текстів - як авторитетних, ключових джерел - до лексикографічного опису.

Теоретико-прикладну значущість авторських словників важко переоцінити. Та все ж у скерованості на інтегральний лінгвістичний опис закладено найширші перспективи для наукової рефлексії.

\section{Література}

1. Богомолов Н. А. [Рец. на кн.] : Словарь языка русской поэзии ХХ века / Н. А. Богомолов ; [сост. : В. П. Григорьев и др.] : в 2 т. - М. : Языки славянской культуры, 2001 ; 2003. - (Studia filologica) [Текст] / Н. А. Богомолов // Русский язык в научном освещении. - 2004. - № 2. - С. 277-280.

2. Бук С. Письменницька лексикографія та корпус текстів [Текст] / Соломія Бук // Магістр гри слова : філолог. дослідж., присвяч. 60-річчю проф. Ф. С. Бацевича / укл.: Оксана Ясіновська, Лідія Сваричевська. - [Луцьк] : [Твердиня], 2009. - С. 42-56.

3. Ганжа С. А. Словник фразеологічних одиниць епістолярної спадщини Лесі Українки [Текст] / С. А. Ганжа, І. В. Донюш, М. П. Войтенко. - Дніпропетровськ : Пороги, 2009. - 36 с.

4. Гельгардт Р. Р. Словарь языка писателя [Електронний ресурс] / Р. Р. Гельгардт // Русская авторская лексикография XIX - XX веков : антология / сост. : Е. Л. Гинзбург [и др.] ; отв. ред. Ю. Н. Караулов. - М. : Азбуковник, 2003. - 512 с. - Режим доступу : http://slovari.ru/default.aspx?s=0\&p=5316\&0a0=1888

5. Гинзбург Е. Л. Альтернативы писательской лексикографии. II [Текст] / Е. Л. Гинзбург // Вестник МГУ. Серия 19 «Лингвистика и межкультурная коммуникация». -2000 . - № $2-$ С. 27-42.

6. Голованевский А. Л. «Поэтический словарь Ф. И. Тютчева»-полный толковый словарь одного автора : традиции и новаторство : [Електронний ресурс] / А. Л. Голованевский // Институт русского языка им. В. В. Виноградова Российской академии наук : [сайт]. - Електронні дані. - Режим доступу : http://www.ruslang.ru/?id=seminar_aut_lexicogr 180510

7. Григорьев В. П. Поэтика слова (на материале русской советской поэзии) [Текст] / В. П. Григорьев. - М. : Наука, 1979. - 344 с.

8. Гриценко П. Ідіолект і текст [Текст] / Павло Гриценко // Лінгвостилістика: об'єкт стиль, мета - оцінка : [зб. наук. праць] / відп. ред. В. Г. Скляренко. -К. : [б. в.], 2007. - С. $16-43$. 
9. Гриценко П. Ю. «Слово поза словником» : реєстр словника як проблема сучасної тлумачної лексикографії [Текст] / П. Ю. Гриценко // Українська лексикографія в загальнослов'янському контексті: теорія, практика, типологія. Ларисі Григорівні Скрипник / [відп. ред. І. С. Гнатюк] ; Нац. акад. наук України, Ін-т укр. мови. - К. : [Видавн. дім Дмитра Бураго], 2011. - С. 238-249.

10. Демська О. Текстовий корпус : ідея іншої форми [Текст] / Орися Демська. - К. : [ВПЦ НаУКМА], 2011. - 284 с.

11. Єрмоленко С. Я. Мовно-естетичні знаки культури в історії літературної мови [Текст] / С. Я. Срмоленко // Мовознавство. - 2007. - № 4-5. - С. 3-12.

12. Загребельний П. Спроба автокоментаря [Текст] / Павло Загребельний // Урок української. - 2001. - № 11-12. - С. 38-42.

13. Карпова О. М. Современная картина шекспировской лексикографии [Текст] / О. М. Карпова // Вестник Воронежского государственного университета. Серия «Лингвистика и межкультурная коммуникация». - 2001. - Вып. 1. - С. 104-110.

14. Пашковська Г. В. Словник мовних особливостей Івана Нечуя-Левицького [Текст] / Ганна Пашковська ; [за ред. Ю. Л. Мосенкіса]. - К. ; [Умань] : [Софія], 2010. - 72 с.

15. Пінчук С. П. Словник літературознавчих термінів Івана Франка [Текст] / С. П. Пінчук, Є. С. Регушевський ; [відп. ред. М. Х. Коцюбинська]. - К. : Наукова думка, 1966. - 272 с.

16. Регушевський Є. С. Словник мовознавчих термінів Івана Франка [Текст] / Є. С. Регушевський. - Сімферополь : Доля, 2002. - 119 с.

17. Словарець до Г. Юлїя Цезара війни з Галійцями [Текст] / зладив Юлїян Кобилянський. - Чернівцї : Руска Рада, 1907. - 107 с.

18. Словник української мови [Текст] : в 11 т. / [редкол.: І. К. Білодід та ін.] ; Акад. наук Укр. РСР, Ін-т мовознавства ім. О. О. Потебні. - К. : Наукова думка, 1970-1980.

19. Ставицька Л. О. Естетика слова в українській поезії $10-30$ рр. ХХ ст. [Текст] / Леся Ставицька. - К. : Правда Ярославичів, 2000. - 156 с.

20. Тростогон М.А. Словник іншомовної лексики наукових та публіцистичних праць І. Я. Франка [Текст] / М. А. Тростогон. - Вінниця : Континент-ПРИМ, 2001. - 96 с.

21. Українська мова : енциклопедія [Текст] / редкол. : Русанівський В. М. [та ін.]. [3-є вид., зі змін. і доповн.]. - К. : Вид-во «Українська енциклопедія» ім. М. П. Бажана, 2007. $-856 \mathrm{c}$.

22. Фразеологія перекладів Миколи Лукаша [Текст] : словник-довідник / [укл. : О. І. Скопненко, Т. В. Цимбалюк] ; Нац. акад. наук України, Ін-т мовознавства ім. О. О. Потебні. - К. : Довіра, 2003. - 736 с.

23. Цимбалюк-Скопненко Т. В. Українська авторська лексикографія : здобутки та перспективи [Текст] / Тетяна Цимбалюк-Скопненко // Українська мова. - 2010. - №2. C. $3-14$.

24. Шестакова Л. Л. Проблемы терминологии в сфере авторской лексикографии [Текст] / Л. Л. Шестакова // Известия РАН. Серия литературы и языка. - 2010. - Т. 69. № 4. - C. 3-11.

25. Шчэрбін В. К. Некаторыя аспекты агульнай тэорыі лексікаграфіі [Текст] / В. К. Шчэрбін // Слово и словарь. Vocabulum et vocabularium. - Харьков Клагенфурт, 2011. - Вып. 12. - С. 10-14.

26. Щерба Л. В. Опыт общей теории лексикографии [Текст] // Щерба Л. В. Языковая система и речевая деятельность / Л. В. Щерба. - Л. : Наука, 1974. - С. 265-304.

27. Hartmann R. R. K. Dictionary of lexicography [Текст] / R. R. K. Hartmann and Gregory James. $-\left[2^{\text {nd }}\right.$ revised ed.]. - London ; New York : Routledge / Taylor \& Francis Group, 2001. - 176 p. 